\title{
Design and Analysis of 300MW Solar Configuration and its Comparison with Quaid-e-Azam Solar Park
}

\author{
Iqra Akram ${ }^{1,2}$, Muhammad Awais ${ }^{2,3}$, Adnan Bashir ${ }^{2}$, Rana Abdul Jabbar Khan ${ }^{4}$, Jamshed Iqbal ${ }^{1,5}$ \\ ${ }^{1}$ Department of Electrical Engineering, FAST National University, Islamabad, Pakistan \\ ${ }^{2}$ Department of Electrical Engineering, University of Engineering \& Technology, Lahore, Pakistan \\ ${ }^{3}$ Department of Electrical Engineering, Information Technology University, Lahore, Pakistan \\ ${ }^{4}$ National Transmissions and Dispatch Company, Lahore Pakistan \\ ${ }^{5}$ Electrical and Computer Engineering Department, University of Jeddah, Saudi Arabia
}

\begin{abstract}
Pakistan's recent energy crisis demands efficient utilization of renewable energy resources. The country, being richest with respect to solar potential, is experiencing a remarkable progress in power generation from Photovoltaic sources. Quaid-e-Azam Solar Park (QASP) is an example to improve the efficiency in term of Performance Ratio (PR) and energy injected into grid. In an attempt to further elevate the efficiency, the present work proposes configuration consisting of modules and inverters with low temperature coefficient. Based on meteorological data obtained from Meteonorm/NASA, performance of the proposed configuration is simulated in PVsyst and is then compared with that of QASP. Comparative results indicate that the proposed configuration annually improves PR by a factor of $3-4 \%$ while increasing the energy injected into the grid by $4.5 \mathrm{MW}$. It is anticipated that physical realization of the proposed configuration will improve energy yield.
\end{abstract}

Keywords-PV system, Solar configuration, Energy efficiency, Performance Ratio, QASP

\section{INTRODUCTION}

Pakistan is facing severe energy crisis at present. Tremendous efforts are being made to offer continuous and reliable solutions by exploring renewable energy resources to overcome the crisis [1]. Solar energy is an ideal source of renewable energy having highest potential in the world [2], which offers environmental friendly [3] drastic change in the energy by reducing carbon gas emission [4]. There are two ways of harnessing solar energy to generate electricity: Photovoltaic (PV) and Concentrated Solar Power (CSP).

The later offers higher efficiency compared with the former one. However, in terms of deployment duration and costs related with installation, $\mathrm{O} \& \mathrm{M}$ and levelization, $\mathrm{PV}$ outperforms than CSP [5]. Given the financial constraints and an urge for a quick renewable solution in Pakistan, PV has been primarily the main source of generating electric power in the country. Grid connected PV systems employ direct conversion of sunlight into electricity which is then fed into the grid without involving storage batteries.

The two key factors pertinent to energy efficiency are Performance Ratio (PR) and the amount of energy injected into the grid [6]. PR depends upon several factors including ambient temperature, efficiency of the module, efficiency of the inverter, losses due to environmental effects etc. The main factor that affects PR is the ambient temperature. For regions with high temperatures (e.g. in Southern Punjab), PV panels with relatively lower temperature coefficients are preferred to minimize deficiency in efficiency due to rise in temperature.

The present work proposes a 300MW solar configuration designed in PVSyst software and analyzes its $\mathrm{PR}$ and injected energy. The proposed configuration is then compared with $300 \mathrm{MW}$ equivalent configuration of Quaide-Azam Solar Park (QASP) w.r.t. both key factors. Practically, QASP has a capacity of $100 \mathrm{MW}$, however, for the sake of fair comparison; the equivalent configuration of
QASP is designed using same inverters and modules as being actually used. Table 1 lists the two configurations of QASP with temperature coefficient of 0.41 . In contrast with JA Solar and Trina modules, the proposed configuration uses Sunpower modules to reduce the coefficient so as to improve PR.

Overall system block diagram is conceptualized in Fig 1. Parameters collected from data sources (NASA/Meteonorm) include temperature, pressure and irradiance. The collected data is used by PVsyst to analyze and compare QASP and proposed configuration w.r.t. PR, energy injected to grid and losses of the system.

TABLE 1

CONFIGURATIONS FOR PV SYSTEM DESIGN AND ANALYSIS

\begin{tabular}{|c|c|c|c|c|}
\hline \multirow[b]{2}{*}{$\begin{array}{c}\text { Configuration } \\
\text { (System) }\end{array}$} & \multirow[b]{2}{*}{ Inverter } & \multicolumn{3}{|c|}{ Module } \\
\hline & & Name & $\begin{array}{l}\text { Temp. } \\
\text { Coeff. }\end{array}$ & $\begin{array}{c}\text { Efficiency } \\
\text { (\%age) }\end{array}$ \\
\hline $\begin{array}{l}\text { Conf. 1 } \\
\text { (QASP) }\end{array}$ & Sungrow & JA Solar & 0.41 & 15.28 \\
\hline $\begin{array}{l}\text { Conf. 2 } \\
\text { (QASP) }\end{array}$ & TBEA & Trina & 0.41 & 14.84 \\
\hline $\begin{array}{l}\text { Conf. } 3 \\
\text { (Proposed) }\end{array}$ & Sungrow & Sunpower & 0.38 & 20.1 \\
\hline
\end{tabular}

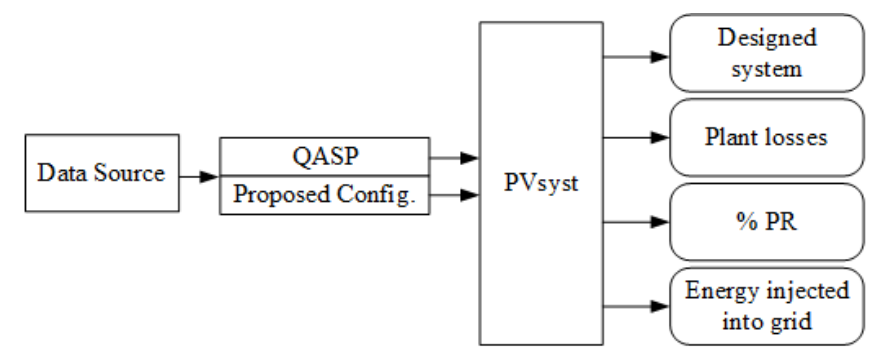

Fig. 1. Functional block diagram.

The remaining paper is organized as follows; Section II reports state-of-the-art on PV systems from grid perspectives. Section III presents design and simulation results of the proposed configuration while Section IV discusses its comparative analysis with reference to QASP. Finally Section V comments on conclusion.

\section{LITERATURE REVIEW}

An in-depth review of literature reported during the last decade revealed the potential of standalone solar PV systems as well as grid-connected systems. This is primarily driven by 'green' nature of solar energy that is catching wider interest of scientific community at domestic and commercial levels.

Hasimah et al. have simulated various modular technologies for Malaysian sites to meet the energy demand [7]. Based on the results obtained from 'RETScreen Clean 
Energy Management' software and PVsyst, they concluded that mono-crystalline and poly-crystalline give higher returns of energy. Karki et al. compared two PV systems; one installed in Berlin while other located in Kathmandu [8]. They observed that the later system comparatively generates $70 \%$ more energy due to higher solar irradiations on the solar module. Another study by Raj et al. considered $100 \mathrm{~kW}_{\mathrm{p}}$ system and investigated that the simulation results obtained using PVsyst are reasonably close to the actual data measured from sunny web box [9].

Putra et al. simulated three different demands $(1 \mathrm{~kW}$, $5 \mathrm{~kW}, 10 \mathrm{~kW}$ ) for three Indian sites [10]. Using three types of modules, they estimated the available energy and cost of the generated energy. They highlighted technical feasibility of hybrid PV systems from physical perspectives.

Truong et al. designed a system with a demand of $15 \mathrm{~kW}_{\mathrm{p}}$ [11]. With a peak power generation range of 9$5.5 \mathrm{~kW}_{\mathrm{p}}$, the presented system produces annual energy of $19348 \mathrm{kWh}$. Another study [12] conducted by Yadav et al. simulated $1 \mathrm{kWp}$ PV system using PVsyst for Hamipur (India) site. The system produces energy of $1356 \mathrm{kWh}$ per year with a PR of $72.4 \%$.
Another simulation study conducted on a $19.8 \mathrm{~kW}_{\mathrm{p}}$ British site by Pillai et al. deduced that PV system is not economically feasible as a backup [13]. Srivastava and Giri also simulated PV system for a site in Gorakhpur (India) for a demand of $150 \mathrm{~kW}_{\mathrm{p}}$. The energy injected into grid is $901.22 \mathrm{kWh}$ per year with a PR of $83.1 \%$ [14]. Irwan et al. simulated a PV system for a $150 \mathrm{~kW}_{\mathrm{p}}$ site located in Kangar (Malaysia) and showed results for standalone PV system [15].

Quesada et al. carried out simulation for a 7.2 $\mathrm{KW}_{\mathrm{P}} \mathrm{PV}$ system based on data from different sources and concluded that different data sources produced different results [16]. Tallab and Malek simulated $1 \mathrm{MW}_{\mathrm{p}}$ system for Algerian site and concluded that tilt angle should be changed in summer and winter to enhance efficiency [17]. Compared with fixed modules, this change increases the energy by $5 \%$. Morshed et al. simulated PV system for a demand of $2 \mathrm{~kW}_{\mathrm{p}}$ using three tools; PVsyst, Homer and SolarMAT. They concluded that PVsyst is a better tool for designing a PV system compared to other two softwares [18].

Table 2 summarizes up-to-date literature review of demands and energy injected into grid for various locations.

TABLE 2

DEMANDS AND ENERGY INJECTED INTO GRID FOR VARIOUS LOCATIONS

\begin{tabular}{|c|c|c|c|c|c|c|c|}
\hline No. & Location(s) & Country & $\begin{array}{l}\text { Latitude } \\
\text { (N) }\end{array}$ & $\begin{array}{l}\text { Longitude } \\
\text { (E) }\end{array}$ & Module name & $\begin{array}{l}\text { Demand } \\
\left(\mathbf{W}_{\mathrm{p}}\right)\end{array}$ & $\begin{array}{l}\text { Energy injected into grid } \\
(\mathrm{KWh} / \mathrm{yr})\end{array}$ \\
\hline 1 & Senai & Malaysia & $1.4^{\circ}$ & $103.4^{\circ}$ & $\begin{array}{l}\text { 1) Shell Ultra 85-P } \\
\text { 2) BP Solar-380X } \\
\text { 3) BP Solar-Millenia MST }\end{array}$ & $500-600 \mathrm{M}$ & $\begin{array}{l}\text { 1) } 136.4 \\
\text { 2) } 69.2 \\
\text { 3) } 65.5[7]\end{array}$ \\
\hline 2 & $\begin{array}{l}\text { 1) Berlin } \\
\text { 2) Kathmandu }\end{array}$ & $\begin{array}{l}\text { 1) Germany } \\
\text { 2) Nepal }\end{array}$ & $\begin{array}{l}\text { 1) } 52.3^{\circ} \\
\text { 2) } 27.5^{\circ}\end{array}$ & $\begin{array}{l}\text { 1) } 13.2^{\circ} \\
\text { 2) } 58^{\circ}\end{array}$ & $250 \mathrm{~W}_{\mathrm{p}}$ sayoHIT-H250E01 & $60 \mathrm{k}$ & $\begin{array}{l}\text { 1) } 53813 \\
\text { 2) } 91154[8]\end{array}$ \\
\hline 3 & $\begin{array}{l}\text { 1)Aceh } \\
\text { Singkil } \\
\text { 2) Alor } \\
\text { 3) Raja Amapt }\end{array}$ & Indonesia & $\begin{array}{l}\text { 1) } 2^{\circ} 21.5^{\prime} \\
\text { 2) } 8^{\circ} 17.6^{\prime} \\
\text { (3) } 0^{\circ} 23^{\prime}\end{array}$ & $\begin{array}{l}\text { 1) } 97^{\circ} 52.3^{\prime} \\
\text { 2) } 124^{\circ} 33.2^{\prime} \\
\text { 3) } 130^{\circ} 52.5^{\prime}\end{array}$ & $\begin{array}{l}\text { 1) Honda highlander } \\
\text { 2) Honda EG6500CXS } \\
\text { 3) Honda Highlander } \\
\text { SF7000-DXE }\end{array}$ & $1 \mathrm{k}-5 \mathrm{k}-10 \mathrm{k}$ & $\begin{array}{l}\text { 1) } 4.644-7.591-14.230 \\
\text { 2) } 4.777-10.469-18.71 \\
\text { 3) } 4.916-7.519-15.057[10]\end{array}$ \\
\hline 4 & Jaipur & India & $26.9124^{\circ}$ & $75.7873^{\circ}$ & STP25000TL-30 & $1 \mathrm{k}$ & $\begin{array}{l}437.92 \text { (Forecasted) } \\
421.242 \text { (Recorded) [9] }\end{array}$ \\
\hline 5 & Hanoi & Vietnam & $21^{\circ}$ & - & XL-SW-335 & $15 \mathrm{k}$ & $19348[11]$ \\
\hline 6 & Hamipor & India & $31^{\circ} 2^{\prime}$ & $76^{\circ} 5^{\prime}$ & STP 150-24B & $1 \mathrm{k}$ & $1356.0[12]$ \\
\hline 7 & Gorakhpur & India & $26.7^{\circ}$ & $83.4^{\circ}$ & SU-250 & $500 \mathrm{k}$ & $901220[14]$ \\
\hline 8 & Kangar & Malaysia & $6.43^{\circ}$ & $100.19^{\circ}$ & Unisolar & 252 & $735.84[15]$ \\
\hline 9 & M'sila & Algeria & $34.8^{\circ}$ & $4.2^{\circ}$ & YL250P-32b & $1 \mathrm{M}$ & $1805000[17]$ \\
\hline
\end{tabular}

\section{SIMULATION OF PROPOSED CONFIGURATION}

In case of grid-connected system, the grid provides battery backup [19]. The proposed system consists of three main stages; PV array, Inverter and Output interface. PV array is a source of DC power. To handle variations in the power generated by PV system, a combiner box is used to permit injection of fixed voltage into the next stage. In inverter, DC voltage is converted into AC for consumption in grid. A central inverter resides in the proposed configuration. The third stage provides output interface and handles injection of the generated energy into grid as shown in Fig. 2.

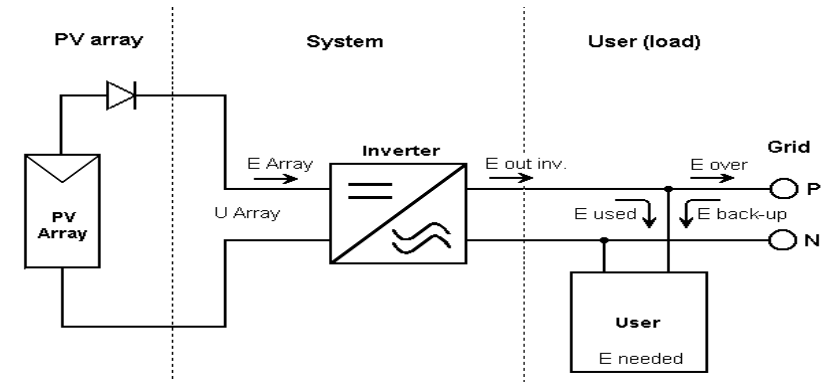

Fig. 2. Schematic diagram of the system.
In case of heavy or commercial loads, the energy can also be directly obtained from PV system instead of grid. A standard configuration also includes a protection phase; however, due to its insignificant impact on the output, we have not shown this phase in the schematics.

The process of designing a PV system for the proposed configuration starts with the selection of geographical site. Entering longitude, latitude and azimuthal information in PVsyst automatically permits data acquisition from NASA/Meteonorm. This is followed by selection of inverter and module in PVsyst for the configuration 3 listed in Table 1 and Fig. 3. We have used poly-crystalline technology in PV modules due to its better yield as reported in [7]. PVsyst automatically collects all the specifications and ratings of the selected components from the specified libraries.

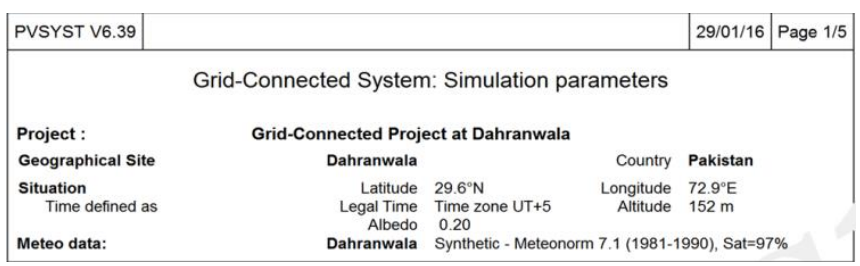

Fig. 3. Geographical information of site.

The next step in simulation is to specify power requirement or area. Based on user's input, the software 
computes number of modules, inverters and their arrangement and determines best operating points. It also suggests tilt angle of the modules, area required and other related factors as illustrated in Fig. 4.

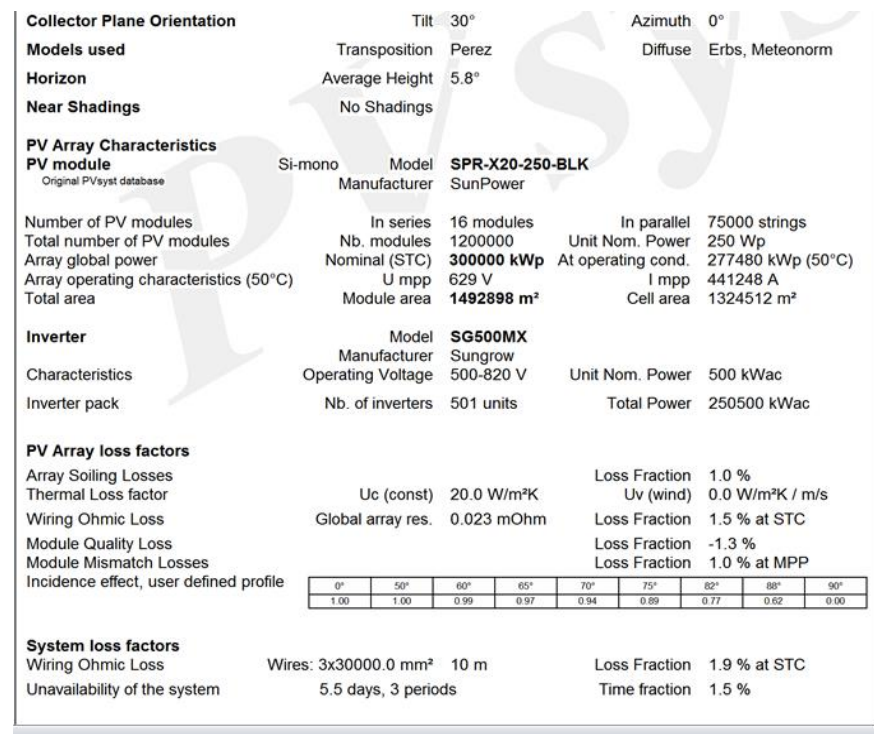

Fig. 4. Parameters values for proposed configuration.

Main parameters of the system (Fig. 4 and Fig. 5) include; nominal AC and DC power, total number of modules, number of inverters, arrangement of modules in series and parallel combinations, annual energy, PR etc.

\begin{tabular}{|c|c|c|c|c|}
\hline $\begin{array}{l}\text { Main system parameters } \\
\text { Horizon } \\
\text { PV Field Orientation } \\
\text { PV modules } \\
\text { PV Array } \\
\text { Inverter } \\
\text { Inverter pack } \\
\text { User's needs }\end{array}$ & $\begin{array}{r}\text { System type } \\
\text { Average Height } \\
\text { titt } \\
\text { Model } \\
\text { Nb. of modules } \\
\text { Model } \\
\text { Nb. of units } \\
\text { Unlimited load (grid) }\end{array}$ & $\begin{array}{l}\text { Grid-Connected } \\
5.8^{\circ} \\
30^{\circ} \\
\text { SPR-X20-250-BLK } \\
1200000 \\
\text { SG500MX } \\
501.0\end{array}$ & $\begin{array}{r}\text { azimuth } \\
\text { Pnom } \\
\text { Pnom total } \\
\text { Pnom } \\
\text { Pnom total }\end{array}$ & $\begin{array}{l}0^{\circ} \\
250 \mathrm{Wp} \\
30000 \mathrm{kWp} \\
500 \mathrm{~kW} \mathrm{ac} \\
250500 \mathrm{~kW} \mathrm{ac}\end{array}$ \\
\hline $\begin{array}{l}\text { Main simulation results } \\
\text { System Production }\end{array}$ & $\begin{array}{l}\text { Produced Energy } \\
\text { Performance Ratio PR }\end{array}$ & $\begin{array}{l}502979 \mathrm{MWh} / \text { year } \\
80.2 \%\end{array}$ & ecific prod. & $1677 \mathrm{kWh} / \mathrm{kW}$ p/year \\
\hline
\end{tabular}

Fig. 5. System energy and PR for proposed configuration.

Detailed monthly results include power produced per month, system losses, PR and energy injected into the grid as shown in Fig. 6 and Fig. 7. Irradiation (global horizontal and global diffused), ambient temperature and system efficiency etc. on monthly basis are tabulated in Table 3. Fig. 8 presents the power lost due to auxiliary losses.

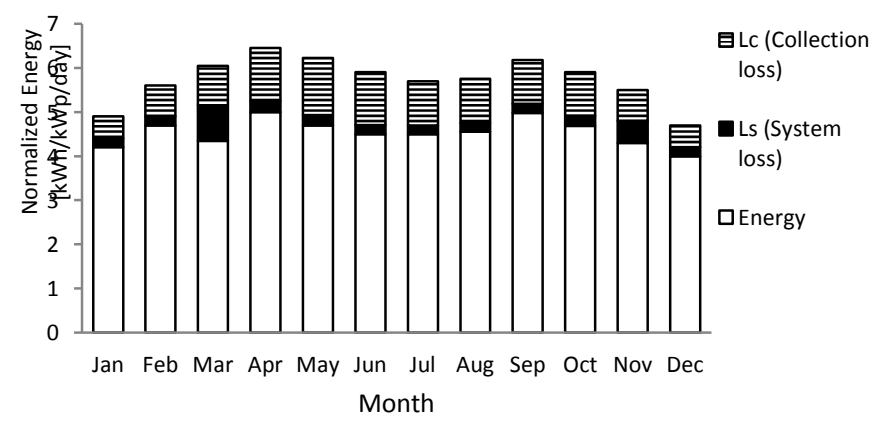

Fig. 6. Normal power per month for proposed configuration.

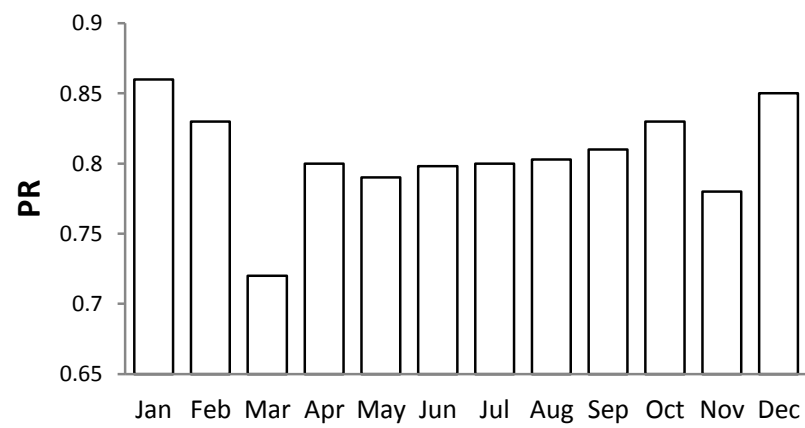

Month

Fig. 7. PR for proposed configuration.

TABLE 3

ANNUAL ENERGY AND ARRAY EFFICIENCY OF PROPOSED CONFIGURATION

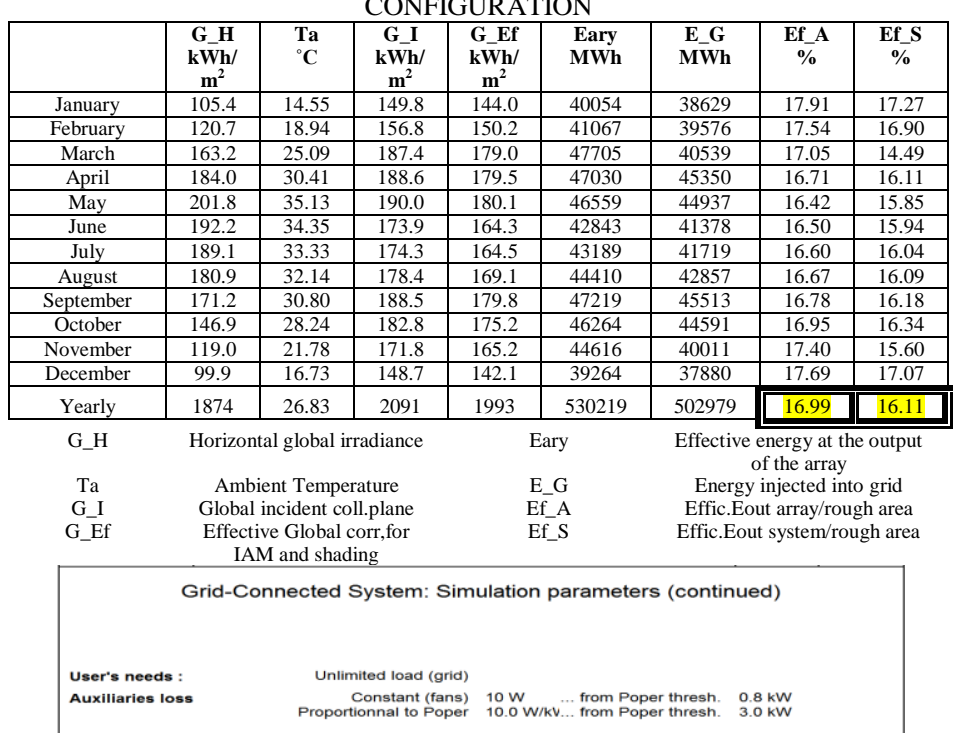

Fig. 8. 300MW system auxiliary losses.

\section{COMPARISON BETWEEN THREE CONFIGURATIONS}

Results obtained corresponding to the three configurations mentioned in Table 1 are then compared. Comparison parameters include PR, energy injected into grid and losses.

Comparing efficiency/area given in Table 3 for various configurations, it is found that in case of QASP, configurations 1 and 2, this value is $11.83 \%$ and $11.37 \%$ respectively. The proposed configuration over-performs since it offers an efficiency of $16.11 \%$. Also, the amount of energy injected into the grid is higher in case of the proposed configuration as compared to QASP configurations as listed in Tables 3-5.

TABLE 4

ANNUAL ENERGY AND ARRAY EFFICIENCY FOR QASP CONFIGURATION 1

\begin{tabular}{|l|l|l|l|l|l|l|l|l|}
\hline & $\begin{array}{l}\mathrm{G} \_\mathrm{H} \\
\mathrm{kWh} / \\
\mathrm{m}^{2}\end{array}$ & $\begin{array}{l}\mathrm{Ta} \\
{ }^{\circ} \mathrm{C}\end{array}$ & $\begin{array}{l}\mathrm{G} \text {-I } \\
\mathrm{kWh} / \\
\mathrm{m}^{2}\end{array}$ & $\begin{array}{l}\mathrm{G} \_ \text {Ef } \\
\mathrm{kWh} / \\
\mathrm{m}^{2}\end{array}$ & $\begin{array}{l}\text { Eary } \\
\text { MWh }\end{array}$ & $\begin{array}{l}\text { E_G } \\
\text { MWh }\end{array}$ & $\begin{array}{l}\text { EA_G } \\
\text { MVAh }\end{array}$ & $\begin{array}{l}\text { Ef_S } \\
\%\end{array}$ \\
\hline January & 156.0 & 14.15 & 222.7 & 213.8 & 58574 & 56074 & 59025 & 12.43 \\
\hline February & 120.7 & 18.94 & 156.8 & 150.2 & 39828 & 38144 & 40152 & 12.01 \\
\hline March & 163.2 & 25.09 & 187.4 & 179.0 & 45665 & 43797 & 46102 & 11.54 \\
\hline
\end{tabular}




\begin{tabular}{|c|c|c|c|c|c|c|c|c|}
\hline April & 184.0 & 30.41 & 188.6 & 179.5 & 44667 & 38799 & 40841 & 10.16 \\
\hline May & 201.8 & 35.13 & 190.0 & 180.1 & 44061 & 42344 & 44572 & 11.01 \\
\hline June & 192.2 & 34.35 & 173.9 & 164.3 & 40864 & 39268 & 41335 & 11.15 \\
\hline July & 189.1 & 33.33 & 174.3 & 164.5 & 41375 & 39755 & 41847 & 11.26 \\
\hline August & 180.9 & 32.14 & 178.4 & 169.1 & 42400 & 40714 & 42857 & 11.27 \\
\hline September & 171.2 & 30.80 & 188.5 & 179.8 & 44855 & 43049 & 45315 & 11.28 \\
\hline October & 146.9 & 28.24 & 182.8 & 175.2 & 44067 & 42280 & 44506 & 11.42 \\
\hline November & 119.0 & 21.78 & 171.8 & 165.2 & 42968 & 41189 & 43357 & 12.84 \\
\hline December & 99.9 & 16.73 & 148.7 & 142.1 & 38404 & 33074 & 34814 & 10.98 \\
\hline Year & 1925 & 26.26 & 2164 & 2063 & 530219 & 498487 & 524724 & 11.37 \\
\hline G_H & \multicolumn{3}{|c|}{ Horizontal global irradiance } & Eary & & \multicolumn{3}{|c|}{$\begin{array}{l}\text { Effective energy at the output of } \\
\text { the array }\end{array}$} \\
\hline $\begin{array}{l}\text { Ta } \\
\text { G_I }\end{array}$ & \multicolumn{3}{|c|}{$\begin{array}{l}\text { Ambient Temperature } \\
\text { Global incident coll.plane }\end{array}$} & $\begin{array}{l}\text { E_G } \\
\text { EA_G }\end{array}$ & & \multirow{2}{*}{\multicolumn{3}{|c|}{$\begin{array}{l}\text { Energy injected into grid } \\
\text { Apperent energy to the grid } \\
\text { Effic.Eout system/rough area }\end{array}$}} \\
\hline G_Ef & \multicolumn{3}{|c|}{$\begin{array}{l}\text { Effective Global corr,for the } \\
\text { IAM and shading. }\end{array}$} & $\mathrm{Ef}_{-} \mathrm{S}$ & & & & \\
\hline
\end{tabular}

TABLE 5

ANNUAL ENERGY AND ARRAY EFFICIENCY FOR QASP CONFIGURATION 2

\begin{tabular}{|c|c|c|c|c|c|c|c|c|}
\hline & $\begin{array}{l}\mathrm{G} \_\mathrm{H} \\
\mathrm{kWh} / \\
\mathrm{m}^{2}\end{array}$ & $\begin{array}{l}\mathrm{Ta} \\
{ }^{\circ} \mathrm{C}\end{array}$ & $\begin{array}{l}\mathrm{G} \_\mathrm{I} \\
\mathrm{kWh} / \\
\mathrm{m}^{2}\end{array}$ & $\begin{array}{l}\text { G_Ef } \\
\mathrm{kWh} / \\
\mathrm{m}^{2}\end{array}$ & $\begin{array}{l}\text { Eary } \\
\text { MWh }\end{array}$ & $\begin{array}{l}\text { E_G } \\
\text { MWh }\end{array}$ & $\begin{array}{l}\text { EA_G } \\
\text { MVAh }\end{array}$ & ${ }_{\%}^{\text {Ef_S }}$ \\
\hline January & 105.4 & 14.55 & 149.8 & 144.0 & 39423 & 37993 & 39992 & 12.91 \\
\hline February & 120.7 & 18.94 & 156.8 & 150.2 & 40043 & 38566 & 40595 & 12.52 \\
\hline March & 163.2 & 25.09 & 187.4 & 179.0 & 45995 & 44318 & 46650 & 12.04 \\
\hline April & 184.0 & 30.41 & 188.6 & 179.5 & 45053 & 39298 & 41366 & 10.61 \\
\hline May & 201.8 & 35.13 & 190.0 & 180.1 & 44456 & 42929 & 45188 & 11.51 \\
\hline June & 192.2 & 34.35 & 173.9 & 164.3 & 41221 & 39802 & 41896 & 11.65 \\
\hline July & 189.1 & 33.33 & 174.3 & 164.5 & 41712 & 40280 & 42400 & 11.77 \\
\hline August & 180.9 & 32.14 & 178.4 & 169.1 & 42747 & 41243 & 43413 & 11.77 \\
\hline September & 171.2 & 30.80 & 188.5 & 179.8 & 45237 & 43592 & 45886 & 11.78 \\
\hline October & 146.9 & 28.24 & 182.8 & 175.2 & 44428 & 42809 & 45062 & 11.92 \\
\hline November & 119.0 & 21.78 & 171.8 & 165.2 & 43249 & 41654 & 43846 & 12.35 \\
\hline December & 99.9 & 16.73 & 148.7 & 142.1 & 38576 & 33473 & 35197 & 11.45 \\
\hline Year & 1874 & 26.83 & 2091 & 1993 & 530219 & 485918 & 511492 & 11.83 \\
\hline G_H & \multicolumn{3}{|c|}{ Horizontal global irradiance } & Eary & & \multicolumn{3}{|c|}{$\begin{array}{l}\text { Effective energy at the output of } \\
\text { the array }\end{array}$} \\
\hline $\mathrm{Ta}$ & \multirow{2}{*}{\multicolumn{3}{|c|}{$\begin{array}{l}\text { Ambient Temperature } \\
\text { Global incident coll.plane }\end{array}$}} & E_G & & \multirow{3}{*}{\multicolumn{3}{|c|}{$\begin{array}{l}\text { Energy injected into grid } \\
\text { Apperent energy to the grid } \\
\text { Effic.Eout system/rough area }\end{array}$}} \\
\hline G_I & & & & EA_G & & & & \\
\hline G_Ef & $\begin{array}{l}\text { Effecti } \\
\text { IAM a }\end{array}$ & $\begin{array}{l}\text { Globa } \\
\text { shading }\end{array}$ & corr,for & $\mathrm{Ef} \_\mathrm{S}$ & & & & \\
\hline
\end{tabular}

Fig. 9 presents comparative results of the three configurations in terms of their monthly PR. It can be seen that the proposed configuration (Conf. 3) over-performs its counterparts through almost all the year. This is due to careful selection of its underlying modules which have higher efficiency and lower temperature coefficient (see Table I).

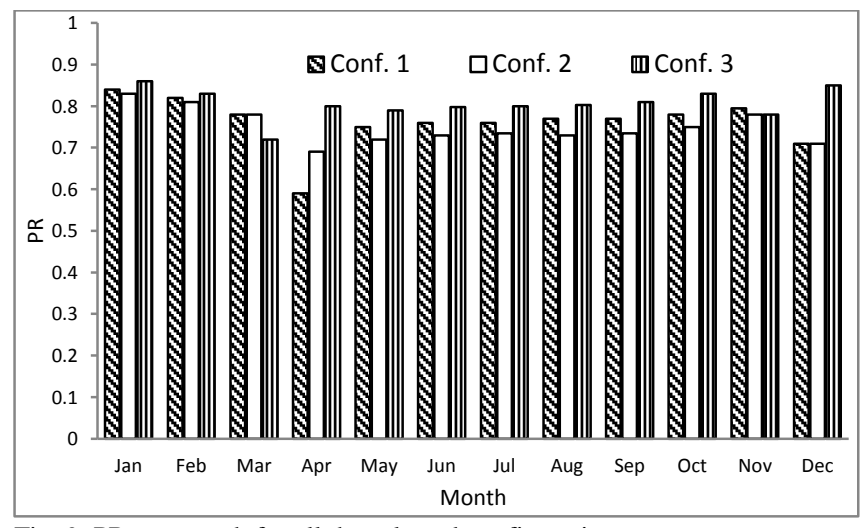

Fig. 9. PR per month for all the selected configurations.

Normalized energy for all the configurations is depicted in Fig. 10. Simulation results indicate that the monthly energy produced is comparatively larger in case of the proposed configuration in comparison with QASP configurations. Collection losses $\left(\mathrm{L}_{\mathrm{c}}\right)$ and System losses $\left(\mathrm{L}_{\mathrm{s}}\right)$ are relatively less in the proposed configuration.

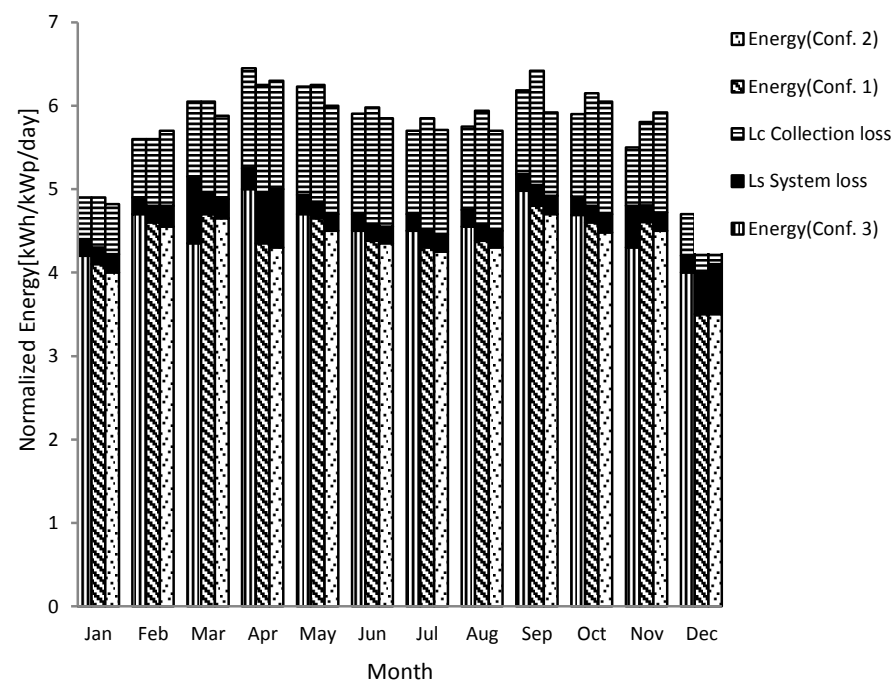

Fig. 10. Normalized energy for all the selected configurations.

Fig. 9 and 10 respectively presented monthly comparative results in terms of PR and energy injected into grid. To analyze the performance on a wider spectrum, Table 6 lists the comparison results on annual basis. Again, the proposed configuration depicts superior performance compared to QASP configurations with reference to PR as well as output energy.

TABLE 6

PR AND ENERGY PRODUCED ANNUALLY BY VARIOUS CONFIGURATIONS

\begin{tabular}{|c|c|c|}
\hline Configuration & PR (\%) & $\begin{array}{c}\text { Energy produced } \\
\text { (MWh) }\end{array}$ \\
\hline Conf. 1 & 77.5 & 485918 \\
\hline Conf. 2 & 76.8 & 498487 \\
\hline Conf. 3 & 80.2 & 502979 \\
\hline
\end{tabular}

The comparative results can also be stated in terms of system losses. The design which suffers from larger losses exhibit lower PR and thus lesser energy injected into the grid. In case of PV system, losses due to ambient temperature are the most dominant ones. The module efficiency and so overall PR of the system are inversely proportional to ambient temperature. Addition of energy due to module quality is higher in case of conf. 3 as compared to other configurations.

TABLE 7

LOSS DUE TO TEMPERATURE AND MODULE QUALITY LOSSES

\begin{tabular}{|c|c|c|}
\hline Configuration & $\begin{array}{l}\text { Loss due to } \\
\text { temperature }\end{array}$ & Module quality loss \\
\hline Conf. 1 & $-12.9 \%$ & $+0.7 \%$ \\
\hline Conf. 2 & $-13.4 \%$ & $+0.7 \%$ \\
\hline Conf. 3 & $-9.3 \%$ & $+1.3 \%$ \\
\hline
\end{tabular}

Losses other than the ones due to ambient temperature have no dominant effects on changing PR and energy 
injected into grid. This is obvious from Table 8 which presents global incidence on collector plane and far shading/horizon. No remarkable difference can be seen in far shading/horizon.

TABLE 8

IMPACT OF OTHER LOSSES

\begin{tabular}{|c|c|c|}
\hline Configuration & $\begin{array}{l}\text { Global incident on } \\
\text { coll. plane }\end{array}$ & Far shadings/Horizon \\
\hline Conf. 1 & $+11.6 \%$ & $-2.9 \%$ \\
\hline Conf. 2 & $+12.4 \%$ & $-2.8 \%$ \\
\hline Conf. 3 & $+11.6 \%$ & $-2.9 \%$ \\
\hline
\end{tabular}

Tables 9-11 show that the losses due to soiling factor, irradiance level and module mismatch, ohmic wiring, inverter, auxiliaries, unavailability of system and AC ohmic are not significantly different in all the selected configurations. Thus, it is confirmed that $t$ in our case, $P R$ is mainly dependent on temperature losses of the system.

TABLE 9

LOSSES DUE TO SOILING FACTOR AND IRRADIANCE LEVEL

\begin{tabular}{|c|c|c|}
\hline Configuration & $\begin{array}{c}\text { Soiling loss } \\
\text { factor }\end{array}$ & $\begin{array}{c}\text { Losses due to } \\
\text { irradiance level }\end{array}$ \\
\hline Conf. 1 & $-1 \%$ & $-0.3 \%$ \\
\hline Conf. 2 & $-1 \%$ & $-0.4 \%$ \\
\hline Conf. 3 & $-1 \%$ & $-1.5 \%$ \\
\hline
\end{tabular}

TABLE 10

MODULE MISMATCHES AND OHMIC WIRING LOSSES

\begin{tabular}{|c|c|c|}
\hline Configuration & $\begin{array}{c}\text { Module mismatch } \\
\text { loss }\end{array}$ & Ohmic wiring loss \\
\hline Conf. 1 & $-1 \%$ & $-1.1 \%$ \\
\hline Conf. 2 & $-1 \%$ & $-1.1 \%$ \\
\hline Conf. 3 & $-1 \%$ & $-1.1 \%$ \\
\hline
\end{tabular}

TABLE 11

AUXILIARIES (FAN, OTHERS), UNAVAILABILITY OF THE SYSTEM AND AC OHMIC LOSSES

\begin{tabular}{|l|l|l|l|l|}
\hline Configuration & $\begin{array}{l}\text { Inverter } \\
\text { Loss }\end{array}$ & $\begin{array}{l}\text { Auxiliaries } \\
\text { Loss }\end{array}$ & $\begin{array}{l}\text { Unavailabilit } \\
\text { y of Sys }\end{array}$ & $\begin{array}{l}\text { AC } \\
\text { Ohmi } \\
\text { c loss }\end{array}$ \\
\hline Conf. 1 & $-1.5 \%$ & $-1 \%$ & $-1.6 \%$ & $-1.1 \%$ \\
\hline Conf. 2 & $-2 \%$ & $-1 \%$ & $-1.6 \%$ & $-1.1 \%$ \\
\hline Conf. 3 & $-1.5 \%$ & $-1 \%$ & $-1.7 \%$ & $-1 \%$ \\
\hline
\end{tabular}

\section{CONCLUSION}

This work proposes a configuration of PV based system of 300MW capacity. Selection of inverters and modules has been carefully done to reduce losses thereby enhancing PR and energy injected into the grid. The designed configuration is then subjected to rigorous analysis in PVsyst. Finally, a comparison with a $300 \mathrm{MW}$ equivalent of an existing solution (i.e. QASP) is presented to validate efficacy of the proposed configuration. Our work improves $\%$ PR of QASP from $76 \%$ to $80 \%$, enhances energy injected into grid by $4.5 \mathrm{MW}$ and decreases temperature losses by a factor of $4 \%$.

\section{REFRENCES}

M. Irfan, J. Iqbal, A. Iqbal, Z. Iqbal, R. A. Riaz, and A. Mehmood, "Opportunities and challenges in control of smart
grids-Pakistani perspective," Renewable and Sustainable Energy Reviews, vol. 71, pp. 652-674, 2017.

[2] A. Blakers, P. Devine-Wright, D. L. Gazzoni, A. G. Hestnes, E Kituyi, J. Kretzschmar, et al., "Research and development on renewable energies: A global report on photovolatic and wind energy " International Science Panel on Renewable Energies, Paris, ISBN 978-0-930357-72-6, 2009.

[3] S. Showalter, F. Wood, and L. Vimmerstedt, "Energy efficiency and renewable energy research and deployment in meeting greenhouse gas mitigation goals: The case of the LiebermanWarner climate security act of 2007, Technical Report NREL/TP-6A2-47213, ," National Renewable Energy Laboratory, US June 2010.

[4] E. N. Kumi and A. Brew-Hammond, "Design and analysis of 1MW grid-connected solar PV system in Ghana, African Technology Policy Studies Network, Working paper series, no. 78," 2013.

[5] J. N. Mayer, S. Philipps, Noha Saad Hussein, T. Schlegl, and C. Senkpiel, "Current and future cost of photovoltaics - Long-term scenarios for market development, sytem prices and LCOE of utility scale PV systems, Study by Fraunhofer-Institute for Solar Energy Systems, Germany on behalf of Agora Energiewende," 2015 .

[6] T. Dierauf, A. Growitz, S. Kurtz, J. L. B. Cruz, E. Riley, and C. Hansen, "Weather-corrected performance ratio, Technical report NREL/TP-5200-57991," National Renewable Energy Laboratory, 2013.

[7] A. Hasimah, M. Khalid, and Y. H. Mohammad, "Assessment of PV cell performance under actual Malaysia operating condition," in IEEE Australasian Universities Power Engineering Conference, 2009, pp. 1-5.

[8] P. Karki, B. Adhikary, and K. Sherpa, "Comparative study of grid-tied photovoltaic (PV) system in Kathmandu and Berlin using PVsyst," in IEEE International Conference on Sustainable Energy Technologies, 2012, pp. 196-199.

[9] A. Raj, M. Gupta, and S. Panda, "Design simulation and performance assessment of yield and loss forecasting for 100 $\mathrm{KWp}$ grid connected solar PV system," in International Conference on Next Generation Computing Technologies, 2016, pp. 528-533.

[10] A. W. Putra, E. Kamandika, S. Rosyadi, A. Purwadi, and Y. Haroen, "Study and design of hybrid off-grid PV-generator power system for administration load and communal load at three regions in Indonesia," in International Conference on Power Engineering and Renewable Energy, 2016, pp. 57-62.

[11] N. X. Truong, N. L. Tung, N. Q. Hung, and B. Delinchant, "Grid-connected PV system design option for nearly zero energy building in reference building in Hanoi," in IEEE International Conference on Sustainable Energy Technologies, 2016, pp. 326-331.

[12] P. Yadav, N. Kumar, and S. S. Chandel, "Simulation and performance analysis of a $1 \mathrm{kWp}$ photovoltaic system using PVsyst," in International Conference on Computation of Power, Energy, Information and Communication, 2015, pp. 358-363.

[13] Pillai, Hodgson, Insaurralde, Pinitjitsamut, and Deepa, "The techno-economic feasibility of providing solar photovoltaic backup power," in IEEE International Symposium on Technology and Society, 2016, pp. 1-6.

[14] S. Rachit and V. K. Giri, "Design of grid connected PV system using PVsyst," i-Manager's Journal on Electrical Engineering, vol. 10, pp. 14-18, 2016.

[15] Y. Irwan, A. Amelia, M. Irwanto, W. Leow, N. Gomesh, and I Safwati, "Stand-Alone Photovoltaic (SAPV) system assessment using PVsyst software," Energy Procedia, vol. 79, pp. 596-603, 2015.

[16] B. Quesada, C. Sánchez, J. Cañada, R. Royo, and J. Payá, "Experimental results and simulation with TRNSYS of a 7.2 kWp grid-connected photovoltaic system," Applied Energy, vol. 88, pp. 1772-1783, 2011.

[17] R. Tallab and A. Malek, "Predict system efficiency of $1 \mathrm{MWc}$ photovoltaic power plant interconnected to the distribution network using PVsyst software," in IEEE International 
Conference on Renewable and Sustainable Energy, 2015, pp. 1-

4.

[18] M. S. Morshed, S. M. Ankon, M. T. H. Chowdhury, and M. A. Rahman, "Designing of a $2 \mathrm{~kW}$ stand-alone PV system in Bangladesh using PVsyst, Homer and SolarMAT," in IEEE International Conference on Green Energy and Technology, 2015, pp. 1-6.

[19] J. Singh, "Study and design of grid connected solar photovoltaic system at Patiala, Punjab," Thesis Master of Engineering, Power System and Electric Drive, Electrical and Instrumentation Engineering Department, Thapar University, Patiala, India, 2010 . 
